\title{
1. Competition: Terminology and concepts
}

To start with, some conceptual clarifications are necessary. It needs to be emphasized that this is a philosophical reconstruction of primary concepts. My approach here is similar to Rawls's, who describes his theory as a philosophical, not an empirical-psychological, theory. ${ }^{1}$ The following is not concerned with etymology. Indeed, my remarks unquestionably could be worked out etymologically in even greater detail.

Under competition, I understand a situation in which several actors are engaged in a competitive endeavor. In contrast to a struggle or contest, however, it is not primordial and cannot permanently sustain itself. Competition in all its forms rather involves a situation that is only stable because of rules. Competition is a highly artificial construct, which, when left alone, can very easily devolve into a "ruinous competition" or a Hobbesian "war of all against all." It is worth noting that the archliberal Ludwig von Mises, in 1922, already clearly distinguished between competition and struggle: "It is merely a metaphor to call competition competitive war, or simply, war. The function of battle is destruction; of competition, construction." ${ }^{2}$ 
Historically, the Greek author known only as "Anonymous Iamblichi" appears to have first recognized competition as a phenomenon in the 5 th century вс when he tried to explain why the resource-poor Greeks still had a strong economy. ${ }^{3}$

Sandra Richter (2012, pp. 14ff.) has worked out the further conceptual history of "Wettbewerb" /"competition": She points out that Grimm's dictionary identifies "Wettbewerb" as a key concept of the late 18th and 19th centuries, associating it with terms such as rivalry, contest (in the arts, etc.), and the theory from biology of "survival of the fittest."

The English term "competition," on the other hand, stems from the Latin root competere, which is related to competitio, a term from the legal field. It denoted, for instance, a juridical challenge a legal proceeding over a controversial subject, which, nonetheless, is regulated in a certain way. By contrast, the Latin concurrere is clearly related to the military field and the sphere of defense (being found already in the writings of Caesar). Accordingly, competition is understood from the outset as a process which takes place with rules, whereas rivalry is a type of interaction that occurs without them.

Competition does not have to be about money, but it can in fact also center on entirely different goods or objectives. Competition - and this point is critical - is by no means exclusively an economic concept. As a science, economics does not have a monopoly on the concept of competition. 
In the next section, I will discuss several forms of competition that are specifically not of the classical economic variety. These include athletic competition, chivalrous competition, and socialist competition.

Under the term "market," I recognize the establishment of certain economic and technical conditions and the actual implementation of competition. Markets are driven by supply and demand; the market economy thrives on the balancing of both. Competition and rivalry, on the other hand, reflect much more fundamental principles of human coexistence. Just like markets, they need rules to remain stable. However - and here I deliberately part ways with the terminology of some areas of economics - markets are economic in the narrow sense. I therefore ascribe them more to the sphere of the economy: equity markets, commodity markets, goods markets, services markets, etc. I recognize that economists also speak in a broader sense of markets, such as the "Market for Virtue" (Vogel 2006).

Nevertheless, this does not correspond to the wider public understanding. I therefore will continue to view markets here as classical economic variables. The concept of competition is thus highly selective for my purposes and is clearly distinguishable from economic contexts in the narrow sense. Competition is consequently also not a principle that is exclusively inherent to the market economy, but may also be found in contexts that fall very much outside of this realm. 


\section{Different concepts of competition}

\section{Athletic and chivalrous competition}

Athletic competition is probably one of the oldest forms of human competition that is predicated on rules. Since its earliest beginnings, which are suspected to be as early as the Paleolithic period, ${ }^{4}$ human beings have always delighted in competing against one another in sport. Moreover, millions, even billions, of people have enjoyed watching them.

In Germany, as well as in other countries permeated with the spirit of competition such as the UK or US, sport is a national obsession. It is above all amateur athletes of modest ability who often seek to compare themselves with others, to engage them in competition, and to determine who is (supposedly) superior.

To precisely delineate the terms, I speak explicitly here of athletic competition. As explained above, I reserve the word "struggle" to denote a primitive, more or less unregulated state.

The - mostly, but not only - historically significant chivalrous competition started out in the High Middle Ages (see, for instance, Keen 2005). By the term "chivalrous competition," I primarily mean tournaments and other forms of sporting - or more accurately, since the term sport did not exist, 'presporting' - competition among members of the equestrian order. This competition was carried out on the basis of many, sometimes very detailed, 
rules according to a knightly ethos, which was upheld as a matter of honor. This ethos was able to function as long as the mechanisms of honor and the risk of a loss of honor worked as instruments of enforcement.

The ethos continued beyond the Middle Ages. This is demonstrated, for instance, by an anecdote from the Battle of Fontenoy in 1745, in which the French commander supposedly said (indeed the story is probably apocryphal): "Messieurs les Anglais, tirez les premiers!" (Gentlemen Englishmen, you may shoot first!). In the air battles of the First World War, during the times of the Red Baron, moreover, the treatment of enemy combatants was frequently referred to as chivalrous. To be sure, these examples concern the military and have more to do with fighting than competition. They are undoubtedly strongly influenced by the ideals of chivalry, however. I would even venture to say that chivalry still plays a role today. For instance, when motorists stop in narrow streets to let oncoming vehicles pass, they are then often greeted with a short wave. Such a sign is not actually necessary and there is no expectation of any direct consideration in return. Just the same: There is a wave, a wave which says "I respect my fellow traveler." This may, of course, only be a pale imitation of the original, but it appears to be a vestige of chivalry nonetheless. 
Socialist competition

If one needed evidence that the concept of competition is not specifically tied to the market economy, it could be found in the fact that competition is also valued in fundamentally different economic systems. There is ample evidence of this, especially in socialist regimes and thought systems.

Some might be familiar with the principle of "socialist competition." In the West, during the Cold War, it was regularly ridiculed and simply dismissed as a kind of pseudo competition. Supporting this view was the famous extreme example of the legendary East German socialist worker Adolf Hennecke (1905-75). In 1948, he supposedly exceeded his planned target by 387 percent, becoming a role model for all socialist workers. While such incidences of propaganda do not interest me here, it is worth noting that a number of statements stand out over the history of Marxism.

Starting with Marx himself, we read that the activity of the capitalist is only "the effect of the social mechanism, of which he is but one of the wheels" (Capital, Marx and Engels 1959, p. 618). This social mechanism also consists precisely in the competition or the rivalry between the individual capitalists and the individual workers. It is not, however, to be fundamentally abolished, but is also viewed as an inherent principle of the socialist economy (Capital, Marx and Engels 1959, 
p. 345). Marx was therefore not against competition as such - even though he neglects to say anything more about its specific form.

Even more striking is the example of Lenin and a speech he gave in 1917. Lenin is undoubtedly hostile to capitalism. Still, he is not interested in abolishing competition. On the contrary, he criticizes capitalism for destroying competition and replacing the small independent production of goods through monopolies:

Bourgeois authors have been using up reams of paper praising competition, private enterprise, and all the other magnificent virtues and blessings of the capitalists and the capitalist system. Socialists have been accused of refusing to understand the importance of these virtues, and of ignoring "human nature." As a matter of fact, however, capitalism long ago replaced small, independent commodity production, under which competition could develop enterprise, energy and bold initiative to any considerable extent, by large- and very large-scale factory production, joint-stock companies, syndicates and other monopolies. Under such capitalism, competition means the incredibly brutal suppression of the enterprise, energy and bold initiative of the mass of the population, of its overwhelming majority, of ninety-nine out of every hundred toilers; it also means that competition is replaced by financial fraud, nepotism, servility on the upper rungs of the social ladder. (Lenin 1917/1964, p. 404) $)^{5}$

Thus Lenin expressly contrasts competition with phenomena that have a highly negative connotation like nepotism. Socialism, on the other hand, would stimulate real competition for the first time. Of course, Lenin had certain ideas about how competition should be organized. This was 
to be the task of a socialist government, which also meant that banks were to be nationalized and placed under the control of the workers. Although these proposals may be problematic in their specifics, the objective is no less interesting: To produce competition and to bring to bear the full range of talents without uniformity.

Interestingly, a recent critic of capitalism, Stéphane Hessel (1917-2013), took up this thought or at least a version of it. In his main work Time for Outrage! from 2010, he effectively characterizes capitalism throughout as a source of evil and rails against increasing competition and the markets as a whole. However, in the book The Path to Hope, co-written with Edgar Morin, there is a passage ${ }^{6}$ in which both argue for greater individual freedom and the creative competition of individuals to find the best solutions for the crises of the present moment. Thus there is at least the kernel of an argument in favor of competition. At the same time, Hessel denounces oligopolies and monopolies, much like Lenin.

Concepts of competition in non-European cultures

Like many other concepts, competition also is not unchanging with respect to the culture in which it takes place. This applies at least for historical examples. In the modern globalized society, there tend to be fewer and fewer instances of such cultural modalities. Nevertheless, it may be observed that there are cultural influences on values in 
the economy, as regards, for instance, the social embeddedness of corruption, the provisions that are made for the elderly, or issues such as participation in the workplace. As to how far these cultural influences reach and whether they actually cannot be altered in any way due to economic incentives will not be examined here. The present concern is simply to show that competition may take on forms that are quite different from those that are usually cited. Toward this end, we may begin with a historical example.

\section{Testing public officials in ancient China}

For centuries, imperial China had had a very capable bureaucracy. Its proficiency was due in no small measure to the fact that the officials since the Han Dynasty (3rd century BC-3rd century AD) had been selected in an intense performance-based process. Already during the Han period, the first elements of a focus on performance were incorporated into the selection process.

They were then converted into a performancebased testing system in the Sui Dynasty (581-618 AD). The examination first consisted of two parts, a capital city examination of the so-called "Rites Ministry," which primarily tested knowledge, and an employment test of the "Personnel Ministry," which initially favored members of noble families. But this employment test was also abolished in the Song Dynasty (960-1279 AD), so that the selection of officials as early as the first millennium was made on the basis of a purely knowledge-centered 
process. To be effective, it was highly competitive. In Europe, even centuries later, the procedures were hardly comparable (the tests developed centuries later by the Jesuits probably came closest).

The Chinese official examinations were tests which inquired about knowledge of the canonical Confucian texts. The candidates had to be familiar with key books, in particular the "Analects" of Confucius, the works of Mencius, and other texts such as the "Book of Songs," the "Book of Documents," and "I Ching." Failure rates always remained high in ancient China (up to 99 percent), which was partly due to the fact that requirements concerning formal aspects also had an extremely high bar. Beyond this, the external conditions for the candidates were very strenuous. The exam questions, for instance, had to be worked on in shelters that were repeatedly battered by wind and rain. Miyazaki (1976) thus even speaks of China's "examination hell." Even so, there are other assessments that describe the system as a "successful attempt at an intellectual meritocracy" (Crozier 2002).

Clearly, this is not a classic system of economic competition, in which the focus is on money and other material aspects in the narrow sense. Indeed, this would not have been possible in ancient China, whose central modes of thought were rather hostile to economics. Contrary to some popular opinions, this even includes Confucianism. At least in its original form, it was very much rooted in traditional thinking. For 
instance, Confucius speaks of asset accumulation primarily in reference to buying land rather than to trade; this is consistent with the fact that Confucians in the classic mold thought in terms of hierarchies and family bonds and tended to reject risky investments. ${ }^{7}$

It is nevertheless surprising to trace the revival of Confucianism, especially in China since it started instituting market reforms in the 1980s and 1990s. Certainly, Confucianism has not become official state doctrine. Officials still hold fast (at least on paper) to socialist ideals. Confucian thinking, nevertheless, has unquestionably penetrated many aspects of social, political, and economic life in China. Confucian associations, Confucian academies and universities, as well as books on Confucianism are supported with government funds. With the help of Confucian thinking, it is clearly possible to grasp and, to some extent, to understand the modern market economy though Confucius himself primarily wanted to reinforce hierarchy and family.

Experts explain that the reverence shown in Confucianism toward elders and for tradition mainly serves as an insurance policy. Specifically, it serves to indemnify one against total ruin in old age or when one is needy - that is to say, when one is no longer fully competitive. Moreover, this reverence applies precisely only to the elderly and possibly family members, not to one's peers or to those with whom one stands in competition. ${ }^{8}$ For Confucians, then, it is not necessary to 
be motivated by morality or even to be altruistic. It is sufficient, as Confucius himself remarks, to show the enemy (i.e. competitors) respect by, for instance, congratulating him in defeat. As with the familiar ideals of chivalry in the West, this is often tied with rituals.

Although Confucianism cannot be discussed here in detail, by this point it should be apparent why this school of thought is suited to an emerging dynamic market economy. The emphasis that Confucianism places on external, i.e. sanctioned, rules is also apt. Indeed, Confucius' insistence that competition needs to take place under fair rules is amenable with my own view here.

Of course, it is beyond the scope of this book to deal with all forms of competition. However, I will return to other forms of competition in areas such as health and education in the following chapters.

\section{Critics of capitalism: A critique of the market or of competition?}

Just who are the critics of capitalism, market, and competition?

In 2012, the World Economic Forum in Davos kicked off for the first time with a genuine debate about capitalism. It had been spurred by calls from Time magazine and the World Economic Forum itself. Invited participants included representatives of business, trade unions, investors, banks, and economists. What was particularly astonishing about the debate was that nearly all the 
representatives in Davos were in basic agreement: Capitalism in the 21st century faces massive problems and, at least in its present form, is no longer viable over the long term. Sharon Burrow, who has been general secretary of the International Trade Union Confederation since 2010, explained that capitalism has failed to create secure jobs and to distribute wealth more evenly. ${ }^{9}$ And even leading economic spokesmen like Ben Verwaayen, CEO of Alcatel-Lucent 2008-13, remarked on capitalism's "unfulfilled promises." David Rubenstein, a representative of a US private equity firm, noted that capitalism clearly did not "have the ability to manage the ups and downs of the economy," and that it had "not solved the problem of economic inequality."

Still, hardly anyone can lay claim to having a realistic solution. What exactly do we expect of capitalism, other than the elimination of inequality? Even on this point, there is no consensus on whether it should be rejected in principle or whether capitalism actually leads to more inequality. Critics, on the other hand, like to call for more innovation, more education, more free enterprise. These are all things that are not necessarily tied to a specific model of capitalism, and yet they are all made possible by competition.

I argue thus that critics of capitalism are not critics of competition per se. Indeed, it is far easier to convince them of the merits of competition in a more general sense than of the virtues of any particular form of capitalism. 
Another example: Business ethicist and economic critic Ulrich Thielemann is known in German-speaking countries as a critic of corporations and of "economism." In books like System Error: Warum der freie Markt zur Unfreiheit führt (System Error: Why the Free Market Leads to Unfreedom; Thielemann 2009), he rails against the "spirit of greed," against only economically minded executives, and against the maximization of profits. A closer look, though, reveals that he is not actually against competition. Indicating that there are clear benefits to competition under appropriate rules, he says, for instance, that "we need regulatory frameworks that can even organize competition to have an ethical purpose" (Handelszeitung, January 26, 2005). Furthermore, Thielemann accuses countries like Greece of having "too little competition and fundamentally encrusted structures" (Handelszeitung, April 12, 2012). At the end of the day, a vocal critic of capitalism like Thielemann is all for competition given the right conditions.

A third example: Jesuit priest and emeritus business ethics professor Friedhelm Hengsbach (1995) has often criticized the expansion of market-based mechanisms, including commercialization in areas such as social work and health. He has also endorsed the concept of a fair price. Nonetheless, he shows a clear understanding of the ethical benefits of competition. In an extensive interview with the German newspaper Die Zeit, Karl Homann admits: "Competition, where it works, is 
fine - within the framework that the state imposes on it" (Die Zeit, September 24, 2009). Here, too, the critic is not opposed to competition; he then, however, goes on to address the possible starting conditions for participants in competition.

Some critics of capitalism and market - like Pope Francis with his text "Evangelii Gaudium" (2013) - make greed responsible for the alleged failures of capitalism. But is not competition itself to blame? Competition - for which no one is personally responsible, but is rather directly tied to the limiting conditions established by modern societies?

In support of the Pope, a prominent author may be mentioned from the camp of secular economists. Tomáš Sedláček, with his book Economics of Good and Evil (2011), provides a fascinating cultural history of economics. I am sympathetic to many of his theses. Nonetheless, he commits a fundamental mistake in arguing that economic development began with the natural phenomenon of greed. In other words, the point of departure for his hypotheses is not competition, but an inherent trait in the individual actors - an anthropological constant.

If this is true, one must wonder why the economic dynamism of the modern market economy did not develop much earlier. Instead, it took many centuries and many institutionally hastened reforms before the modern market economy could finally "take off."

David Graeber, one of the thought leaders of 
the Occupy movement, claims in his book DebtUpdated and Expanded: The First 5000 Years (2014) that today's market economy and the "excesses" of capitalism were due to certain decisions by various rulers, or entrenched human habits, or simply the evil daemon, money. But what he does not say is that the competition is responsible for many market mechanisms, or that it produces ethical benefits. Instead, again, "greed" alone is highlighted in economics. All other possible human motives seem to be pushed aside (interview in Süddeutsche Zeitung, May 25, 2012).

Such thinking is pervasive in the Occupy movement: Many of their followers do not understand that a general principle of societies like competition might need to be guided by better rules in a different direction. The greed of individuals or certain elites or certain classes, while productive for a market economy, can also always cause problems if misdirected. It is easy to scapegoat a human trait like greed. It is much less easy to do so, however, when it comes to a social principle like competition.

\section{The critique of competition}

We have now looked at a few examples of the critique of capitalism. An even more formidable line of criticism is found in the critique of competition. It is generally manifested in two forms - either in the popular public debate or in the academic debate. 
An example of the former is a statement like the one from Karl-Heinz Brodbeck (Financial Times Deutschland, September 14, 2004), who categorically asserts: "Morality ... is the opposite of competition; its purpose is to include the other - to teach cooperation, not conflict." Along similar lines, Friedhelm Hengsbach (mentioned above) hopes for a "Farewell to the Competitive Society" (Abschied von der Konkurrenzgesellschaft, 1995), and in Hubris (Hybris), Meinhard Miegel (2014) contends that competition is systematically overtaxing all of us. Other examples are cited in this book's later chapters on health (Chapter 6) and ecology (Chapter 4), such as when the president of the German Medical Association Montgomery deems "too much competition" unethical. ${ }^{10}$

A different sort of critique comes from the sociologist Hartmut Rosa. In his article "Competition as a Mode of Interaction" ("Wettbewerb als Interaktionsmodus," Rosa 2006), he fundamentally rejects competition and "competitive society" on the basis of theoretical arguments. Rosa criticizes that, especially in Germany, but also in other countries, competitiveness is the sole criterion for quality. This is allegedly true not only in the economy, but also in all other areas like science and even in kindergarten. While his article seems to be chiefly directed at competition between universities, he formulates his points in a much broader manner. Rosa ultimately puts forward the following arguments: 
First, competition leads to "excess production" (p. 87) and "therefore represents an extremely wasteful form of social organization" (p. 87). This argument, however, was refuted no later than 1968: In his article "Competition as a Discovery Procedure" (1968/2002), Friedrich August von Hayek rebutted this very point. You can only speak of unnecessary excess production when you know in advance what is to be produced, by whom, and what each customer or consumer will want to purchase or consume. The alleged excess production in a functioning competitive market is not superfluous, but rather essential, for it is only through competition that it is possible to arrive at the best and most innovative solution.

Next, Rosa points out that competition strengthens the "natural or social inequalities between people" (2006, p. 93). Existing differences in wealth and education are only amplified and deepened through competition. This argument is completely mistaken, however. First of all, it is certainly true that competition does not make everyone equal. The socialist experiments of the 20th century sufficiently showed that the greatest possible egalitarianism is not desirable. This does not mean, on the other hand, that the less well off are, first and foremost, adversely affected by competition. On the contrary, functioning competition is a win-win situation.

Examples are found in abundance. It can hardly be denied that many former developing and emerging countries in Asia and South America, 
now also in Africa, have benefited from opening themselves more to competition - naturally, in a controlled and regulated way. ${ }^{11}$ Competition even benefits individuals who are less well off: Only in a state of functioning competition can the less fortunate actually rise up in a society and challenge the position of those who are better off. Those who refute this tend to want a socialist society or a traditional class-based state.

Rosa's third argument is that a certain degree of "streamlining" (2006, p. 100) occurs in competition that causes "quirky originality" to disappear. This argument can only be represented by someone who believes that for every problem there is only one solution and only one way. To the contrary: Many roads lead to Rome. This is even true for biological evolution, which amply demonstrates that not just one species entirely wins out against others. There are always distinct habitats that can in fact coexist. ${ }^{12}$ Biological problems have very different solutions. And the same goes for competition. Whether speaking of interior decorating, clothing, brewing, automobiles, services like hairdressing, restaurants, and private education providers as well as books, artworks, music, and much more, it can hardly be maintained that competition in these areas leads to uniformity, that it permits or only results in one product in the respective market.

Rosa's fourth and final argument is that competition in a system can change from being a means to an end in itself. As an end in itself, 
the preservation of competitiveness "inevitably becomes an opportunistic value and goal" (2006, p. 103). This is why it is presumably necessary to contemplate radically restrictive reform of the social organization of modern societies with respect to competition. While the basic point here deserves to be taken very seriously, it needs to be weighed against theoretical (see Chapter 2) as well as empirical arguments. If it were actually true that competition is ultimately senseless and of no use to anyone, then we would have a serious problem. I will present several arguments on education in this vein in Chapter 5. In this case, however, the outcomes of competition are tied to its rules.

Rosa, by contrast, claims that competition is generally "not neutral in relation to the 'last humanly possible opinions' on the world and life in the sense of Weber." Competition even has "significant, indeed, totalizing consequences for the individual possibilities of life" (2006). Of course, one should always have the chance to start over. But it is unavoidable that there are going to be prima facie "losers" in competition. Companies also need to be able to go bankrupt. It would not be desirable for competition to wreak absolutely no "creative destruction" (Schumpeter 1912/1934). The new can only come into the world when individuals are liberated from convention and when companies - as collective actors - are able to orient themselves in completely new ways and flexibly adapt to changing situations. Those 
who initially lose should be helped (temporarily) so that they can get back into the "game." But this already brings us to the heart of the discussion on the ethical qualities of the competition, which will be the topic of Chapter 2 . 